Scientia Marina 71(3)

September 2007, 485-497, Barcelona (Spain)

ISSN: 0214-8358

\title{
Cell cycle analysis of brain cells as a growth index in larval cod at different feeding conditions and temperatures
}

\author{
RAFAEL GONZÁLEZ-QUIRÓS ${ }^{1,2}$, ITZIAR MUNUERA ${ }^{1}$ and ARILD FOLKVORD ${ }^{3}$ \\ ${ }^{1}$ Departamento de Biología de Organismos y Sistemas (Área de Ecología), Universidad de Oviedo, c/ Catedrático Rodrigo \\ Uría s/n, Oviedo 33071, Spain. \\ ${ }^{2}$ Present address: I.F.A.P.A. Centro El Toruño. Carretera N-IV km 654. Camino tiro del pichón s/n, Apdo. Correos 16, \\ 11500 El Puerto de Santa María, Cádiz. E-mail: rafael.gonzalezquiros.ext@juntadeandalucia.es \\ ${ }^{3}$ Department of Biology, High Technology Center, University of Bergen, N-5020 Bergen, Norway.
}

SUMMARY: The percentage of cells dividing in a specific tissue of individual larvae can be estimated by analyzing DNA per cell by flow cytometry. An experimental test was carried out with cod (Gadus morhua) larvae, with brain as the target tissue, to validate this technique as an appropriate growth index for larval fish. Standard length (SL), myotome height, and $\% \mathrm{~S}$-phase (\% of cells in the S-phase of the cell-division cycle) variability were analyzed, with temperature $\left(6\right.$ and $\left.10^{\circ} \mathrm{C}\right)$, food level (high- and no-food) and larval developmental stage (first feeding, pre-metamorphosis and post-metamorphosis) as independent factors. Cod larvae grew faster (in SL) and presented a higher \%S-phase under high-food conditions. Larval SL increased with temperature in rearing and experimental tanks. However, there was a significant interaction between temperature and food in the $\% \mathrm{~S}$-phase. There were no significant differences in the $\% \mathrm{~S}$-phase between 6 and $10^{\circ} \mathrm{C}$ at high-food levels. We suggest that this result is a consequence of temperature-dependency of the duration of the cell cycle. In the absence of food, larvae at $10^{\circ} \mathrm{C}$ had a lower $\% \mathrm{~S}$-phase than larvae at $6^{\circ} \mathrm{C}$, which may be related to increased metabolic costs with increasing temperature. Considering the effect of temperature, the mean $\% \mathrm{~S}$-phase explained $74 \%$ of the variability in the estimated standard growth rate.

Keywords: brain, cell cycle, cod larvae, flow cytometry, food, growth index, temperature.

RESUMEN: ANÁLISIS DEL CICLO CELULAR EN CÉLULAS DEL CEREBRO COMO ÍNDICE DE CRECIMIENTO EN LARVAS DE BACALAO A DIFERENTES CONDICIONES DE ALIMENTO Y TEMPERATURA. - El porcentaje de células en divisón en un determinado tejido de una larva de pez se puede estimar analizando la cantidad de ADN por célula mediante citometría de flujo. Se realizó un experimento con larvas de bacalao (Gadus morhua), analizando células de cerebro, para validar esta técnica como índice de crecimiento en larvas de peces. Se analizó la variabilidad de la longitud estándar (SL), la altura del tronco medida en el ano, y el $\% \mathrm{~S}\left(\%\right.$ de células en fase $\mathrm{S}$ del ciclo celular), con temperatura $\left(6\right.$ y $\left.10^{\circ} \mathrm{C}\right)$, nivel de alimento (alto y sin alimento) y estado de desarrollo larvario (comienzo de la alimentación, pre-metamorfosis y post-metamorfosis) como factores independientes. Las larvas de bacalao crecieron más rápido (en $\mathrm{SL}$ ) y presentaron mayor $\% \mathrm{~S}$ bajo condiciones de nivel alto de alimento. La SL larvaria incrementó con la temperatura. Sin embargo, se observó una interacción significativa entre temperatura y alimento sobre $\% \mathrm{~S}$. No hubo diferencias significativas en $\% \mathrm{~S}$ entre 6 y $10^{\circ} \mathrm{C}$ en condiciones de nivel alto de alimento. Sugerimos que este resultado es consecuencia de una termo-dependencia en la duración del ciclo celular. En ausencia de alimento, las larvas a $10^{\circ} \mathrm{C}$ presentaron $\% \mathrm{~S}$ más bajos que las larvas a $6^{\circ} \mathrm{C}$, lo que puede estar relacionado con un incremento de los costes metabólicos a mayor temperatura. Considerando el efecto de la temperatura, el \% $\mathrm{S}$ medio explicó el $74 \%$ de la variabilidad de la tasa de crecimiento específica estimada.

Palabras clave: alimento, cerebro, ciclo celular, citometrñia de flujo, índice de crecimiento, larva de bacalao y temperatura. 


\section{INTRODUCTION}

The processes affecting survival of larval and early juvenile stages are the main factors that determine recruitment of pelagic fish. Growth has been proposed to be an important factor for regulating survival due to its influence on the duration of these stages and its interaction with characteristic highmortality rates (Houde, 1987; Pepin, 1991).

A variety of growth and condition indices have been developed in order to understand how environmental conditions affect individual growth rates (see review from Ferron and Leggett, 1994). These include morphometric and histological indices, otolith microstructure analysis and others based on a variety of organic compounds that correlate to growth, such as nucleic acids and certain enzymes. Physiological larval status resulting from recent environmental conditions has been estimated by biochemical analysis of RNA and DNA content of larval homogenates (Clemmesen and Doan, 1996; Folkvord et al., 1997; García et al., 2007). The RNA/DNA index relies on the assumption that the amount of DNA per cell is relatively constant while the amount of RNA varies with physiological status. However, the RNA/DNA index may reflect potential protein synthesis more than growth itself (Ferron and Leggett, 1994).

Theilacker and Shen (1993a, b, 2001), taking into account that larval growth is mainly attained by cell division, proposed analyzing the percentage of cells that are dividing in a specific tissue as a more direct approach to estimating recent growth rate. The division cycle of most cells consists in four coordinated processes: cell growth, DNA replication, distribution of the duplicated chromosomes to daughter cells, and cell division (cytokinesis) (Cooper, 2000). Mitosis (nuclear division) and the timing of DNA synthesis divide the cell cycle in eukaryotes into four discrete phases. The M-phase of the cycle corresponds to mitosis, which is usually followed by cytokinesis. This phase is followed by the $G_{1}$ phase (gap 1), which corresponds to the interval (gap) between mitosis and the initiation of DNA replication. During $\mathrm{G}_{1}$, the cell is metabolically active and grows continuously, but does not replicate its DNA. $\mathrm{G}_{1}$ is followed by the S-phase (synthesis), during which DNA replication takes place. The completion of DNA synthesis is followed by the $G_{2}$ phase (gap 2), during which cell growth continues and proteins are synthesized in preparation for mitosis. Cells in $G_{1}$ may enter a qui- escent stage of the cell cycle called $\mathrm{G}_{0}$, in which they remain metabolically active but no longer proliferate unless induced to return to $\mathrm{G}_{1}$ by appropriate external signals (Cooper, 2000). In the technique used by Theilacker and Shen (1993a, b; 2001), DNA is stained in single cells or nuclei with a fluorescent dye. The intensity of fluorescence per cell is measured by flow cytometry (FC) and, since it corresponds to its amount of DNA, the proportion of cells at each intensity represents the proportion of cells at different cell cycle phases (Fig. 1): (1) cells in the $G_{0}$ and $G_{1}$ phases $\left(G_{0}-G_{1}\right)$ are represented by a peak at low fluorescence; (2) cells in the $G_{2}$ and $M$ phases $\left(G_{2}-M\right)$ correspond with a population that peaks at double fluorescence intensity compared to $G_{0}-G_{1}$ cells; (3) cells that are going through DNA replication (S-phase) fluoresce at intensities ranging between $\mathrm{G}_{0}-\mathrm{G}_{1}$ and $\mathrm{G}_{2}-\mathrm{M}$ peaks. However, this apparently straightforward estimation depends on some critical aspects. FC requires a suspension of individual cells. Cell dissociation from a tissue may produce a certain amount of debris, whereas some cells may still remain aggregated. Fluorescence of aggregates and debris interfere with the target cell populations (see Fig. 1) and therefore with adequate estimation of the percentage of cells at each cell cycle phase (Shankey et al., 1993).

Models suggest that small changes in larval growth rates cause large differences in recruitment size (Houde, 1987; Pepin and Myers, 1991). Temperature and the production and abundance of larval prey have been proposed as the major factors

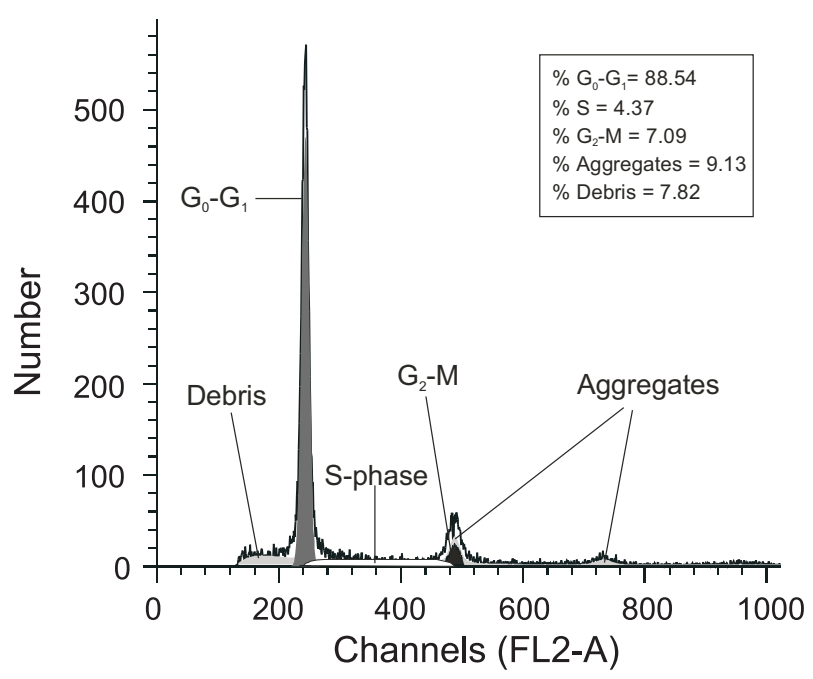

FIG. 1. - A typical display of the computer program used for cell cycle analysis. It shows a histogram of the number of particles at each fluorescence intensity, and modelled fits for each cell cycle phase (G0-G1, S and G2-M), debris and aggregates. 
that regulate larval growth (e.g. Houde, 1989; Leggett and Deblois, 1994). In addition, larval growth variability is also related to the ontogenetic state (Otterlei et al., 1999). Theilacker and Shen (1993a, b, 2001) showed significant differences in the percentage of $\mathrm{S}+\mathrm{G}_{2}-\mathrm{M}$ in brain cells and muscle nuclei between fed and unfed Theragra chalcogramma larvae, although their analysis was restricted to first-feeding larvae under a homogeneous temperature. Bromhead et al. (2000) also observed differences in the $\left(\mathrm{G}_{2}-\mathrm{M}\right) /\left(\mathrm{G}_{0}-\mathrm{G}_{1}\right)$ ratio in brain cells between fed and unfed Galaxias olidus larvae at two different temperatures. However, the interaction between both factors was not tested. In addition, they did not observe significant differences in $\left(\mathrm{G}_{2}-\mathrm{M}\right) /\left(\mathrm{G}_{0}-\mathrm{G}_{1}\right)$ between larvae growing at 12 and $16^{\circ} \mathrm{C}$. Lower values from larvae at $20^{\circ} \mathrm{C}$ were associated with high mortality and attributed to disease and (or) temperature shock. They did observe a significant relationship with larval size, which they attributed to growth variability related to developmental stage. Catalan et al. (2007) observed significant differences in $\mathrm{S}+\mathrm{G}_{2}-\mathrm{M}$ of muscle nuclei between fed and fasted, post-flexion Dicentrarchus larbrax larvae after 2 days.

Our objective was to test the adequacy of cell cycle analysis to study the effect of factors that may have a larger influence on growth variability of fish larvae, including their possible interactions. We used a factorial experimental design which considered temperature, food availability and larval developmental stage. We selected larval Gadus morhua for our experimental test because of the large amount of background information on metabolic rates and condition indices for this species, in field and experi-

TABLE 1. - Unacceptable and medium quality values of parameters, used to establish criteria for discarding cell cycle data. \% BAD, \% of background aggregates and debris is defined as the ratio of model estimated aggregates and debris to total cellular (or nuclei) events in the histogram, over the region from the lowest $G_{0}-G_{1}$ mean to the highest $\mathrm{G}_{2}-\mathrm{M}$ mean. CCE, cell cycle events. NECh, number of events per channel between lowest $G_{0}-G_{1}$ and highest $G_{2}-M$ of the histogram. CV, the variation coefficient of the normal diploid $\left(\mathrm{G}_{0}\right.$ $\mathrm{G}_{1}$ ) cell population. RCS, reduced Chi-square value. RCS is a measure of how well the model describes the observed data.

\begin{tabular}{lcc}
\hline Quality parameter & Unacceptable quality & Medium quality \\
\hline$\%$ of aggregates & $>20$ & $>10$ \\
$\%$ of debris & $>15$ & $>10$ \\
$\%$ of BAD & $>25$ & $>20$ \\
CCE & $<6000$ & $<10000$ \\
NECh & $<90$ & $<100$ \\
CV of $\mathrm{G}_{0}-\mathrm{G}_{1}$ & $>7$ & $>5$ \\
RCS & $>5$ & $>3$ \\
\hline
\end{tabular}

mental studies (e.g. Otterlei et al., 1999; Finn et al., 2002). We used larval brain as the target tissue for estimating the percentage of cell division, even though neural tissue growth presents a slower temporal response under unfavourable growth conditions (Theilacker and Shen, 2001). Brain cells were still preferred, as preliminary FC analysis showed that we were able to obtain more appropriate cell suspensions from larval brain than from larval muscle, based on quality parameters obtained from the FC analysis (see Table 1 for details about quality parameters).

\section{MATERIAL AND METHODS}

\section{Fish and rearing conditions}

Cod eggs were obtained on 20 March 2001 from a naturally spawning broodstock of about 100 repeat spawning Norwegian coastal cod. Temperature during incubation was $6.7 \pm 0.1^{\circ} \mathrm{C}(\mathrm{SD})$, and $50 \%$ hatching (day 0) occurred on April 4. Larvae were transferred on day 2 post hatching to four 1-m rectangular tanks with a rearing volume of $500 \mathrm{~L}$. Approximately 3000 larvae were transferred to four tanks, two of which were kept in a temperature controlled room at $6^{\circ} \mathrm{C}$ and the other two were kept at $10^{\circ} \mathrm{C}$. The seawater was kept stagnant initially and later up to $10 \%$ was exchanged per day in connection with addition of food. The larvae were fed cultured algae, Isochrysis and Rhodomonas (2 L tank ${ }^{-1}$ day $\left.^{-1}\right)$, and natural zooplankton. The larvae were fed in excess, and prey levels were adjusted daily to attain a nominal density of 2000 prey $\mathrm{L}^{-1}$. The main prey items were initially rotifers and copepod nauplii, and subsequently copepodites and adult copepods. Aeration was used in the tanks to maintain oxygen levels sufficiently high and disperse the food for the cod larvae (Otterlei et al., 1999).

\section{Experimental design}

We used a $2 \times 2 \times 3 \times 2$ factorial design to examine the effects of temperature (T; 6 and $10^{\circ} \mathrm{C}$ ), food (HighFood and 0-Food), developmental stage (DS; first feeding, pre metamorphosis and post metamorphosis) and tank $(\mathrm{n}=2)$, which was nested in $\mathrm{T}$ and food.

Larvae were transferred from the rearing tanks to eight experimental tanks, four in each controlled temperature room, at three distinctive developmen- 
tal stages: established first feeding larvae (FF; about $5 \mathrm{~mm}$ standard length (SL) and with no visible yolk remains), a high-growth phase at a late larval stage (Pre-M; 9-10 mm SL; (Otterlei et al., 1999)), and the stage after initiation of metamorphosis (Post-M; about $15 \mathrm{~mm} \mathrm{SL}$ ). See Figure 2 for the timing of transfer to the experimental tanks at each temperature in relation to larval size. These tanks were 60$\mathrm{cm}$ rectangular tanks with approximately $150 \mathrm{~L}$ rearing volume. At each temperature, two of the tanks received algae and zooplankton at the same densities as the rearing tanks (High-Food), while the other two tanks did not receive any plankton (0-Food). Larvae were initially transferred equally from all four rearing tanks to the corresponding experimental tanks at the same temperature, but due to lower availability of larvae in one of the rearing replicates at $10^{\circ} \mathrm{C}$, larvae were sampled from one rearing tank during the latter two developmental stages (transfers). A total of 60 larvae were transferred to each of the experimental tanks during the FF developmental stage, 45-50 in Pre-M, and 45 in Post-M. Ten larvae were sampled from each of the experimental tanks on day 1 and day 5 after transfer between 13:00 and 15:00 hours (local time). The remaining larvae in the experimental tanks were sampled and counted to estimate survival during the experimental period. We considered that 5 days of starvation vs. high feeding conditions would cause a clear effect on larval growth without causing a large larval mortality in starvation treatments that may put into question any significant differences between treatments.

The same day of the transfer to the experimental tanks and the day corresponding to day 5 in the experimental tanks, 10-20 larvae were sampled from the rearing tanks to estimate larval size at the beginning and end of the feeding experiments. Additional samples were taken from the rearing tanks on approximately a weekly basis between the transfers.

\section{Sample processing}

All sampled larvae were length measured (SL) live under a calibrated dissecting microscope, and a digital photo was taken of each larva for later morphometric analysis. After photography, the larvae were rinsed in distilled water, put in an eppendorf tube with a cryoprotectant solution (Table 2), and frozen in liquid nitrogen. SL and myotome height measured at the anus (MYO, Ellertsen et al., 1980) were subsequently measured from the photo images by Image Pro analysis software. Larvae from HighFood treatments that did not have any apparent gut contents were excluded from further analysis $(n=4)$.

Hereafter, only up to 5 larvae sampled on day 5 from each experimental tank were further processed and used for FC analysis (35 in FF, 39 in Pre-M and 40 in Post-M). Larvae were thawed, immediately rinsed in citrate buffer (Table 2) and placed on a microscope slide in a drop of citrate buffer. Under the stereomicroscope, the brain was dissected out and transferred with a micropipette into an eppendorf tube containing $100 \mu \mathrm{L}$ of citrate buffer. The tissue was broken up into a suspension of individual cells by pipetting the solution in and out very gently 10 to 15 times with a 50 to $200 \mu \mathrm{L}$ micropipette set at approximately $100 \mu \mathrm{L}$, trying to avoid creating bubbles. This procedure is one of the most critical aspects of the method as excessively strong pipetting causes a high percentage of debris and aggregates that reduces the quality of the results (see below). Immediately after, $100 \mu \mathrm{L}$ of $0.08 \mathrm{~N} \mathrm{HCL}$ were added to the solution and the sample was kept on ice until DNA staining procedures. Up to 20 larvae were processed at a time within $1.5 \mathrm{~h}$.

Subsequently, samples were centrifuged at $4 \mathrm{G}$ during 5 minutes and the supernatant taken out. Two hundred $\mu \mathrm{l}$ of solution A (Table 2) was added to each sample and the eppendorf tube was gently shaken. The sample was left for 10 minutes at room temperature. Then, $200 \mu \mathrm{l}$ of solution B (Table 2) was added and left at room temperature for another 10 minutes. Finally, $250 \mu \mathrm{l}$ of solution C (Table 2) was added and samples were immediately placed on ice in the dark until FC analysis (not before 10 minutes).

\section{Flowcytometry analysis}

Samples were analyzed with a FACScalibur (Beckton \& Dickinson) FC with an argon-ion laser that produced $15 \mathrm{~mW}$ at $488 \mathrm{~nm}$. The percentage of cells in each cell division phase $\left(\mathrm{G}_{0}-\mathrm{G}_{1}, \mathrm{~S}\right.$ and $\left.\mathrm{G}_{2}-\mathrm{M}\right)$ was estimated from data obtained from the FL2-A channel by modelling carried out with ModFit version 3.0 (Verity Software) (Fig. 1). The model was set with autoaggregates, autodebris, diploid cell cycle without aneuploid population and the S-phase population as a rectangle.

The accuracy of the percentage of cells in each phase estimate is dependant on the number of cells analyzed, the proportion of debris and aggregates, the degree of overlap between $\mathrm{G}_{0}-\mathrm{G}_{1}$ and $\mathrm{S}$ popula- 
TABLE 2. - Solutions used in preserving fish larvae and DNA staining.

\begin{tabular}{|c|c|c|}
\hline Solution & Components & Quantity \\
\hline $\begin{array}{l}\text { Cryoprotectant } \\
(500 \mathrm{ml})\end{array}$ & $\begin{array}{l}\text { Bovine serum } \\
\text { Dimetylsulfoxide } \\
\text { Eagles MEM (Biochrom) }\end{array}$ & $\begin{array}{l}100 \mathrm{ml} \\
100 \mathrm{ml} \\
400 \mathrm{ml}\end{array}$ \\
\hline $\begin{array}{l}\text { Citrate buffer } \\
(1000 \mathrm{ml}) \\
\text { (pH adjusted to } 7.6)\end{array}$ & $\begin{array}{l}\text { Sucrose } \\
\text { Trisodium citrate } 2 \mathrm{H}_{2} \mathrm{O} \\
\text { Dimetylsulfoxide } \\
\text { Distilled water }\end{array}$ & $\begin{array}{l}85.50 \mathrm{~g}(250 \mathrm{mM}) \\
11.76 \mathrm{~g}(40 \mathrm{mM}) \\
50 \mathrm{ml} \\
\text { added to a volume of } 1000 \mathrm{ml}\end{array}$ \\
\hline $\begin{array}{l}\text { Stock solution for } \\
\text { solutions A, B and C } \\
(1000 \mathrm{ml})\end{array}$ & $\begin{array}{l}\text { Trisodium citrate } 2 \mathrm{H}_{2} \mathrm{O} \\
\text { Nonidet-P40 } \\
\text { Spermine tetrahydrochloride } \\
\text { Distilled water }\end{array}$ & $\begin{array}{l}1000 \mathrm{mg}(3.4 \mathrm{mM}) \\
1000 \mu \mathrm{l}(0.1 \% \mathrm{v} / \mathrm{v}) \\
522 \mathrm{mg}(1.5 \mathrm{mM}) \\
\text { added to a volume of } 1000 \mathrm{ml}\end{array}$ \\
\hline $\begin{array}{l}\text { Solution } \mathrm{A} \\
\text { ( } \mathrm{pH} \text { is adjusted to } 7.6 \text { ) }\end{array}$ & $\begin{array}{l}\text { Stock solution } \\
\text { Trypsin }\end{array}$ & $\begin{array}{l}1000 \mathrm{ml} \\
30 \mathrm{mg}\end{array}$ \\
\hline $\begin{array}{l}\text { Solution } \mathrm{B} \\
\text { ( } \mathrm{pH} \text { is adjusted to } 7.6 \text { ) }\end{array}$ & $\begin{array}{l}\text { Stock solution } \\
\text { Trypsin inhibitor } \\
\text { Ribonuclease A }\end{array}$ & $\begin{array}{l}1000 \mathrm{ml} \\
500 \mathrm{mg} \\
100 \mathrm{mg}\end{array}$ \\
\hline $\begin{array}{l}\text { Solution } \mathrm{C} \\
\text { (pH is adjusted to } 7.6 \text { ) }\end{array}$ & $\begin{array}{l}\text { Stock solution } \\
\text { Propidium Iodide } \\
\text { Spermine tetrahydrochloride }\end{array}$ & $\begin{array}{l}1000 \mathrm{ml} \\
416 \mathrm{mg} \\
1160 \mathrm{mg}\end{array}$ \\
\hline
\end{tabular}

tions and to what extent the model adjusts to the observed distribution of events at each fluorescence value (Bauer et al. 1993; Shankey et al. 1993; Verity Software, Inc. unpublished data). In order to ensure standardization and appropriate quality across experimental treatments, sample processing was stopped when the cell counter reached 15000 cells and the criteria for discarding samples from further data analysis (Table 1) were established from a series of parameters obtained from the model, namely: (1) Number of cell cycle events (CCE). Theoretical considerations and empirical observations suggest that a minimum of 10000 (not including debris and aggregates) is necessary for reproducible determination of the S-phase, although this value is controversial (Bauer et al. 1993; Shankey et al. 1993). (2) Number of events per channel (NECh), defined as the number of events per channel between the lowest $\mathrm{G}_{0}-\mathrm{G}_{1}$ and highest $\mathrm{G}_{2}-\mathrm{M}$ of the histogram. Simulation studies indicate that for accurate S-phase estimates there should be an average of approximately 100 NECh (Verity Software, Inc. unpublished data). (3) Percentage of aggregates. (4) Percentage of debris. (5) Background aggregates and debris (\% BAD), defined as the ratio of the model estimated aggregates and debris to total cellular (or nuclei) events in the histogram over the region from the lowest $G_{0}-G_{1}$ mean to the highest $\mathrm{G}_{2}-\mathrm{M}$ mean. Low levels of cell aggregates and debris, and their adequate assessment, are critical for estimating the percentage of cells at each cell cycle phase (Shankey et al., 1993). (6) Variation coefficient of the normal diploid $\left(\mathrm{G}_{0}-\mathrm{G}_{1}\right)$ cell population (CV). CV affects the accuracy of S-phase calculations. It should be $<8 \%$ (Bauer et al. 1993; Shankey et al. 1993). (7) Reduced Chi-Square value (RCS) is a measure of how well the model describes the observed data. Values less than 3.0 represent good fits. Values of 3.0 to 5.0 are considered to be fair, and values greater than 5.0 are poor, and may indicate that the model is not a good match for the histogram (Verity Software, Inc. unpublished data). Samples were rejected if they were over or below a critical value considered unacceptable according to these parameters, or when more than two exceeded medium quality values (Table 1 ).

\section{Statistical analysis}

Two ANOVAs were carried out on Ln SL and \% S-phase as dependent factors, with $\mathrm{T}\left(6\right.$ and $\left.10^{\circ} \mathrm{C}\right)$, DS (FF, Pre-M and Post-M), Food (0-Food and High-Food) and tank (two tanks nested in each combination of $\mathrm{T}$ and food) as independent factors. Exposure to suboptimal growth conditions such as the absence of food may cause a reduction in larval weight that may not be reflected in SL. SL*MYO is a better proxy for larval weight than SL (van der Meeren, 1991). Therefore, differences in the morphometric relationship between SL and MYO may 
be used as a better index of the effect that experimental conditions may exert on larval weight. An ANCOVA analysis was carried out to determine this morphometric variability in the different experimental treatments. Variables were logarithmically transformed to fit variance homogeneity conditions and confirmed to be non-significant using a Cochran Ctest. LnMYO was the dependent variable and $\operatorname{lnSL}$ the covariate. The independent factors were the same as in the other ANOVAs. In each analysis, data were balanced for the different treatments using the mean of the corresponding dependent variable and the mean of the covariant. F-values and their corresponding $p$-values that were obtained from the ANOVAs and ANCOVA of balanced data sets were recalculated following Underwood (1997). Taking into account that Tank was nested in Food and Temperature, a SNK post-hoc test was carried out following Underwood (1997). Average daily mortality after transfer was estimated by assuming a constant mortality rate and correcting for sampled and remaining larvae in the respective tanks.

\section{Estimate of specific growth rate}

In order to analyze the relationship between $\% \mathrm{~S}$ phase and larval growth we estimated the mean larval specific growth rate (SGR) of the larvae from day 1 to day 5 in each experimental treatment $(\mathrm{T} \times$ Food $\times$ DS $\times$ Tank). Larval dry weight (DW; $\mathrm{mg})$ in each larva was estimated based on data from SL (mm) and MYO (mm) (Finn et al., 2002), yielding the equation:

$$
\begin{gathered}
\ln \mathrm{DW}=-3.21+1.37 \ln \left(\mathrm{SL}^{*} \mathrm{MYO}\right), \\
\mathrm{n}=245, \mathrm{R}^{2}=0.997, \mathrm{SE} \text { est. }=0.01
\end{gathered}
$$

The specific growth rate (SGR) between day 1 and day 5 was:

$\mathrm{SGR}=\left(\ln \mathrm{DW}_{5}-\ln \mathrm{DW}_{1}\right) / 4$, where $\mathrm{DW}_{5}$ and $\mathrm{DW}_{1}$ are average estimated dry weights five and one day after transfer respectively.

An ANCOVA analysis was carried out to test for significant effects of temperature on the relationship between SGR and \%S-phase. We considered SGR as the dependent variable, temperature $\left(6\right.$ and $\left.10^{\circ} \mathrm{C}\right)$ as an independent factor and $\% \mathrm{~S}$-phase as the covariate. We tested for significant differences in slopes and intercepts between the linear regression fits for 6 and $10^{\circ} \mathrm{C}$. We fitted a linear regression model of SGR against \%S according to the ANCOVA results.

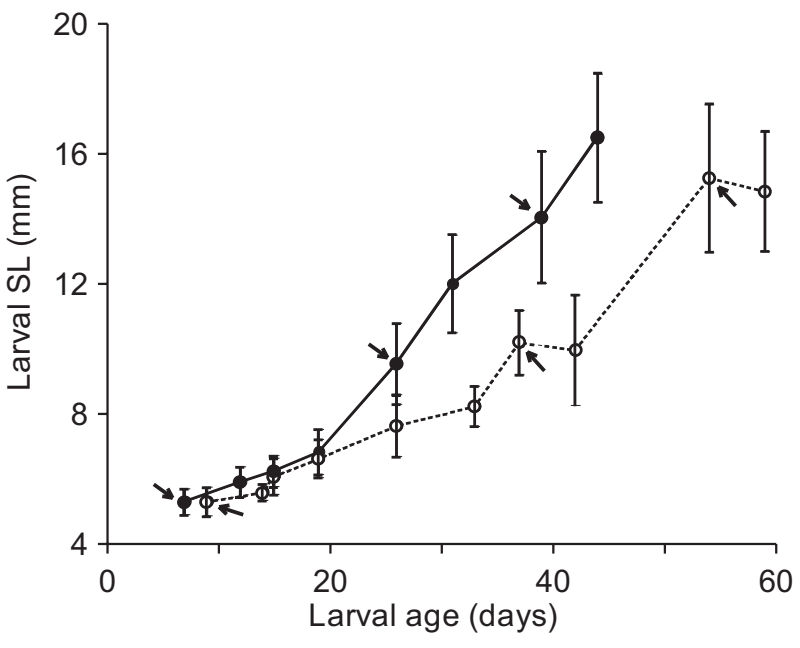

FIG. 2. - Mean and standard deviation of standard length (SL; mm) in rearing tanks at $6^{\circ} \mathrm{C}$ (open circles and dashed line) and $10^{\circ} \mathrm{C}$ (filled circles and continuous line) from the beginning to the end of the experiments. The arrows mark the beginning of the experiments at each Temperature - Developmental Stage.

\section{RESULTS}

Larvae grew faster (in terms of SL) at $10^{\circ} \mathrm{C}$ than at $6^{\circ} \mathrm{C}$. Larvae took 44 days from hatching to grow up to $16.5 \mathrm{~mm}$ (S.D. 1.98) SL at $10^{\circ} \mathrm{C}$ and 59 days to grow up to $14.8 \mathrm{~mm}$ (S.D. 1.84) $\mathrm{SL}$ at $6^{\circ} \mathrm{C}$ (Fig. $2)$. Daily mortality rate after transfer to the experimental tanks was similar in the fed and starved groups and averaged 3.3 and $3.2 \%$ day $^{-1}$ respectively. The mortality rate averaged $8.6 \%$ day $^{-1}$ in the FF period and $0.5 \%$ day $^{-1}$ in the Pre-M and Post-M stages (Table 3). High mortality of FF larvae was possibly due to transfer stress.

$\mathrm{T}$ and Food showed a significant effect on Ln SL of larvae from the experimental treatments (ANOVA, $\mathrm{p}<0.05$, Table 4). As expected, larger larvae were observed at experimental day 5 under

TABLE 3. - Average daily mortality rates $\left(\mathrm{day}^{-1}\right)$ in experiments after transfer at 3 different developmental stages: (1) established first feeding larvae, about $5 \mathrm{~mm}$ standard length (SL) and with no visible yolk remains (FF); (2) high-growth phase at late larval stage, 9-10 mm SL (Pre-M); and after initiation of metamorphosis, about

\begin{tabular}{|c|c|c|c|}
\hline \multirow[b]{2}{*}{ Stage } & \multirow[b]{2}{*}{ Temp } & \multicolumn{2}{|c|}{ Daily mortality rate } \\
\hline & & Fed & Starved \\
\hline FF & $6^{\circ} \mathrm{C}$ & 0.062 & 0.089 \\
\hline $\mathrm{FF}$ & $10^{\circ} \mathrm{C}$ & 0.124 & 0.068 \\
\hline Pre-M & $6^{\circ} \mathrm{C}$ & 0.009 & 0.003 \\
\hline Pre-M & $10^{\circ} \mathrm{C}$ & 0.000 & 0.014 \\
\hline Post-M & $6^{\circ} \mathrm{C}$ & 0.000 & 0.006 \\
\hline Post-M & $10^{\circ} \mathrm{C}$ & 0.000 & 0.009 \\
\hline Average & & 0.033 & 0.032 \\
\hline
\end{tabular}
$15 \mathrm{~mm}$ SL (Post-M). 
TABLE 4. - Results of the ANOVA analysis on larval LnSL at experimental day 5 in each experimental treatment. T, temperature; DS, developmental stage; df, degrees of freedom; MS, mean squares; F, F value; $p$, level of significance. Asterisks denote level of significance: $* p<0.05 ; * * p<0.01 ; * * * p<0.001$.

\begin{tabular}{lcccccc}
\hline Factors and interactions & df effect & MS effect & df error & MS error & F & $p$ \\
\hline T & 1 & 0.180 & 4 & 0.009 & 19.084 & $0.020^{*}$ \\
DS & 2 & 25.074 & 8 & 0.019 & 1296.5 & $0.000^{* * *}$ \\
Food & 1 & 0.650 & 4 & 0.009 & 68.99 & $0.001 * *$ \\
Tank & 4 & 0.009 & 210 & 0.011 & 0.876 & 0.479 \\
T x DS & 2 & 0.057 & 8 & 0.019 & 2.970 & 0.108 \\
T x Food & 1 & 0.041 & 4 & 0.009 & 4.379 & 0.105 \\
DS x Food & 2 & 0.047 & 8 & 0.019 & 2.466 & 0.146 \\
DS x Tank & 8 & 0.019 & 210 & 0.011 & 1.798 & 0.079 \\
T x DS x Food & 2 & 0.060 & 8 & 0.019 & 3.097 & 0.101 \\
\hline
\end{tabular}

TABLE 5. - Results of the 3 ANCOVAs for each DS at experimental day 5. LnMYO, dependent variable; LnSL, covariate. T, temperature; DS, developmental stage; df, degrees of freedom; MS, mean squares; F, F value; $p$, level of significance. Asterisks denote level of significance: $* p<0.05 ; * *<<0.01 ; * * * p<0.001$.

\begin{tabular}{llcccccc}
\hline DS & Factors and interactions & df effect & MS effect & df error & MS error & F & p \\
\hline FF & T & 1 & 0.033 & 4 & 0.027 & 1.252 & 0.326 \\
& Food & 1 & 0.228 & 4 & 0.006 & 8.527 & $0.043 *$ \\
& Tank & 1 & 0.027 & 61 & 0.027 & 4.571 & $0.003 * *$ \\
& T x Food & 4 & 0.035 & 4 & 0.027 & 1.311 & 0.316 \\
\multirow{2}{*}{ Pre-M } & T & 1 & 0.006 & 4 & 0.003 & 1.813 & 0.249 \\
& Food & 1 & 0.277 & 4 & 0.003 & 81.36 & $0.001 * *$ \\
& Tank & 4 & 0.003 & 65 & 0.004 & 0.812 & 0.522 \\
& T x Food & 1 & 0.011 & 4 & 0.003 & 3.303 & 0.143 \\
Post-M & T & 1 & 0.000 & 4 & 0.0025 & 0.001 & 0.974 \\
& Food & 1 & 0.441 & 4 & 0.0025 & 173.9 & $0.000^{* * *}$ \\
& Tank & 4 & 0.003 & 70 & 0.0027 & 0.940 & 0.446 \\
& T x Food & 1 & 0.017 & 4 & 0.0025 & 6.790 & 0.060 \\
\hline
\end{tabular}

High-Food or $10^{\circ} \mathrm{C}$ treatments. These differences were less apparent in the FF stage than in Pre-M and Post-M stages. There were significant differences between the linear regression slopes of lnMYO against $\operatorname{lnSL}$ for the 24 different combinations of treatments $(\mathrm{n}=223 ; \mathrm{F}=2.14 ; \mathrm{p}=0.003)$. The slopes of the Post-M stage cases, mainly at $10^{\circ} \mathrm{C}$, were consistently lower than the slopes of the FF and Pre-M. We therefore carried out 3 separate ANCOVAs, one for each developmental stage. The slopes within FF, Pre-M and Post-M were not significantly different (FF: $\mathrm{n}=70 ; \mathrm{F}=1.52, \mathrm{p}=0.177$. Pre-M $: \mathrm{n}=74 ; \mathrm{F}$ $=1.044 ; \mathrm{p}=0.410$. Post-M: $\mathrm{n}=79 ; \mathrm{F}=0.955 ; \mathrm{p}=$ 0.472). The effect of the covariant (lnSL) was significant in each DS (FF: $\mathrm{n}=70 ; \mathrm{F}=13.34 ; \mathrm{p}<0.01$. Pre-M: $\mathrm{n}=74 ; \mathrm{F}=9.27 ; \mathrm{p}<0.01$. Post-M: $\mathrm{n}=79 ; \mathrm{F}$ $=475.4 ; \mathrm{p}<0.01)$. ANCOVAs also showed significant effect of Food in each DS (Table 5). Adjusted means were calculated in order to remove all differences that could account for $\operatorname{lnSL}$ (the covariate). Lower adjusted means, reflecting a slenderer morphology for a certain SL (and therefore lower larval weight), were observed in larvae at 0 -Food com- pared with High-Food in each of the different cases (Fig. 3). Larvae at 0 -Food and $10^{\circ} \mathrm{C}$ presented lower adjusted means than larvae at 0 -Food and $6^{\circ} \mathrm{C}$ in each larval stage (Fig. 3), although the interaction between $\mathrm{T}$ and Food was not significant at any DS.

According to criteria in Table 1, 45.7, 5.1, and $7.5 \%$ (16, 2, 3 in numbers) of FF, Pre-M and Post$\mathrm{M}$ samples respectively, were discarded from further data analysis. Most FF, rejected cases ( $c$. $70 \% ; \mathrm{n}=11$ ) presented $<6000 \mathrm{CCE}$. The low number of replicates in FF treatments (Fig. 4) prevented us from including this whole data set in the $\% \mathrm{~S}$ phase ANOVA. There was a significant effect of the interaction $\mathrm{T} x$ Food on \%S-phase (only Pre-M and Post-M cases). There were significant differences in all $\mathrm{T} x$ Food pairs, except between $6^{\circ} \mathrm{C}-$ High-Food and $10^{\circ} \mathrm{C}-$ High-Food (SNK test, $p$ $<0.05$; Fig. 5). Treatments with 0 -Food had significantly lower \%S-phase cells than High-Food groups, and among 0 -Food, $10^{\circ} \mathrm{C}$ treatments presented significantly lower $\% \mathrm{~S}$-phase than $6^{\circ} \mathrm{C}$ treatments (Fig. 5). This overall pattern was similar to the pattern observed for the adjusted means 


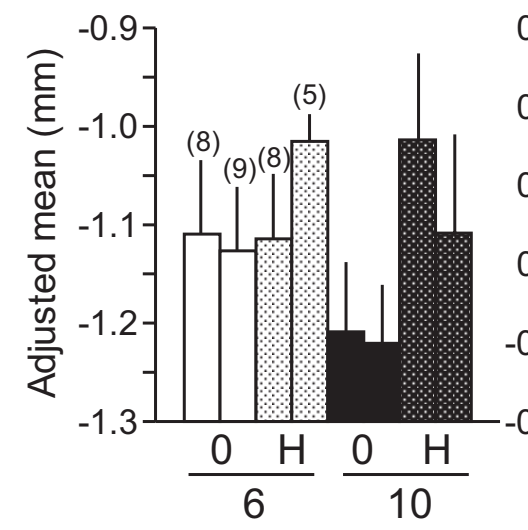

FF

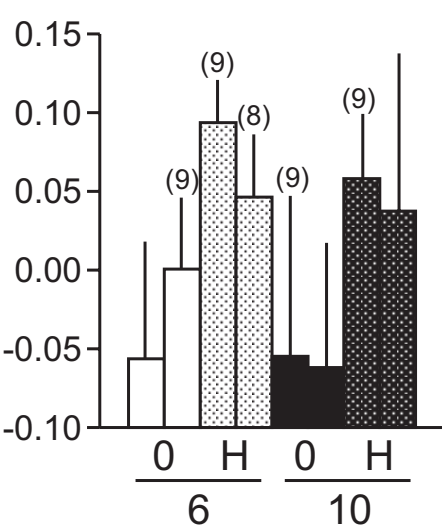

Pre-M

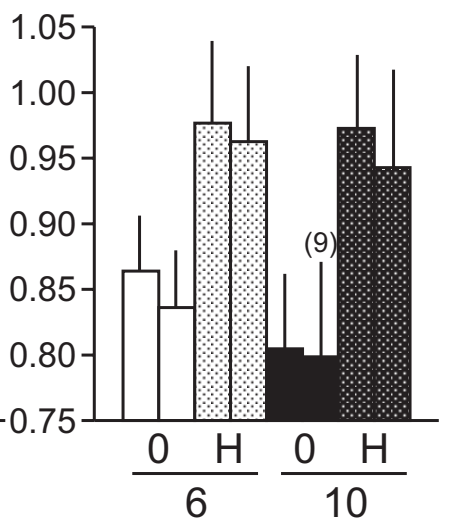

Post-M

FIG. 3. - Adjusted means (bars) and their standard deviation (vertical lines) of Ln MYO (Ln SL as covariate) in each experimental Temperature x Developmental Stage x Food interaction at experimental day $5.6^{\circ} \mathrm{C}$, white background bars; $10^{\circ} \mathrm{C}$, black background bars; 0 Food (0), solid bars; High-Food $(\mathrm{H})$, dotted bars. Each pair case corresponds to two different tanks. FF, established first feeding larvae, about $5 \mathrm{~mm}$ standard length (SL) and with no visible yolk remains; Pre-M, late larval stage, $c$. 9-10 mm SL; Post-M, after initiation of metamorphosis, $c .15 \mathrm{~mm} \mathrm{SL}$. $\mathrm{n}=10$ in all treatments except when indicated in parenthesis on top of the corresponding bar. Adjusted means and their standard deviation were calculated independently at each developmental stage.
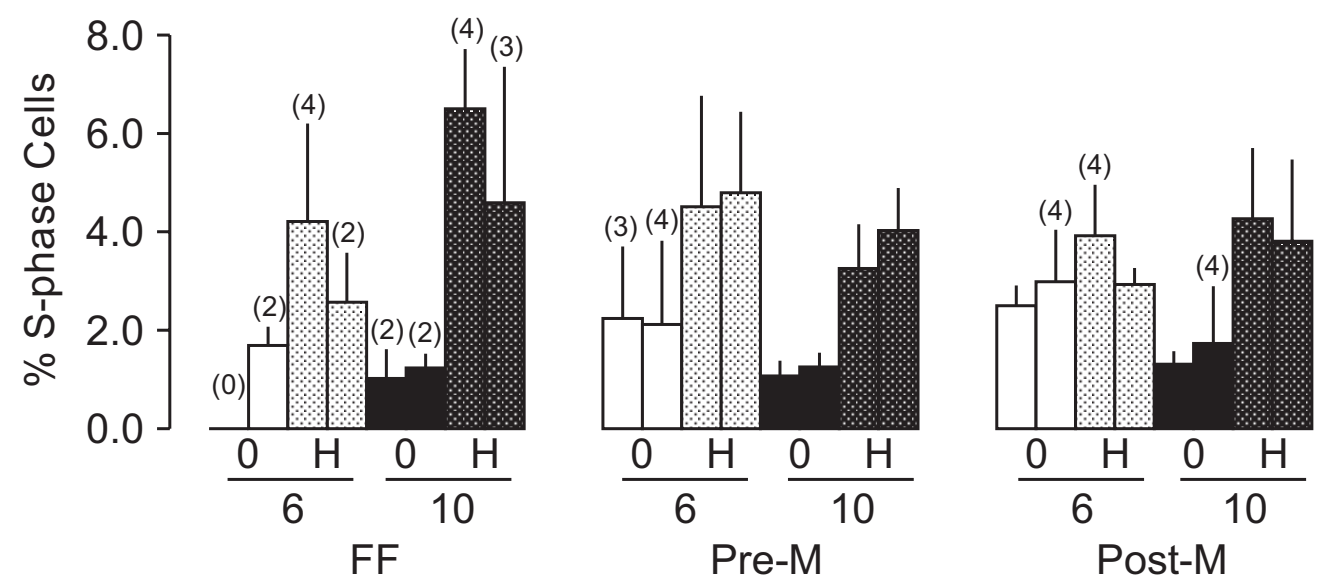

FIG. 4. - As in 3 but for $\% \mathrm{~S}$ cells and $\mathrm{n}=5$ in all treatments except when indicated in parenthesis on top of the corresponding bar.

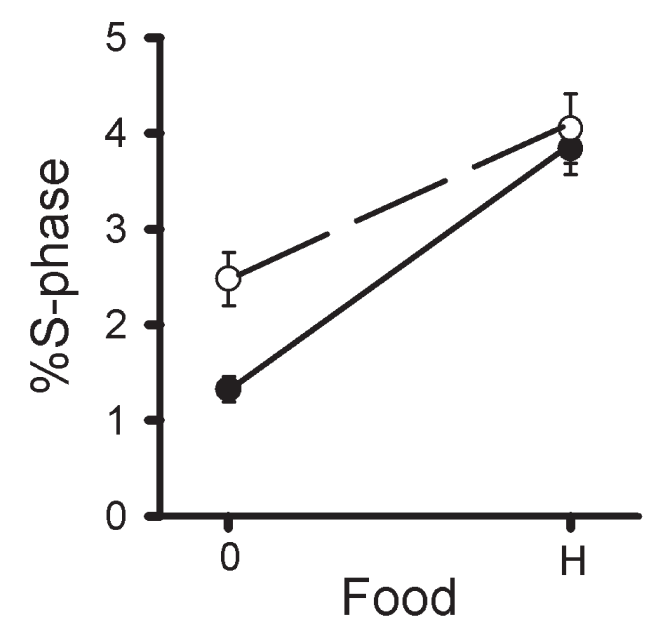

FIG. 5. - Temperature x Food interaction plot. Mean (circles) and standard error (vertical lines) of \% S-phase for Pre-M and Post-M stages (as defined in Fig. 3 caption). $6^{\circ} \mathrm{C}$, open circles and dashed line, and $10^{\circ} \mathrm{C}$, filled circles and continuous line. 0, 0-Food; $\mathrm{H}$, High-Food. in the lnMYO - lnSL ANCOVAs: (1) there were lower adjusted means in treatments with 0-Food, (2) there were no apparent differences between $6^{\circ} \mathrm{C}-$ High-Food and $10^{\circ} \mathrm{C}-$ High-Food, and (3), although the effect of $\mathrm{T}$ was not significant, the $\mathrm{T}$ $x$ Food interaction and adjusted means in $6^{\circ} \mathrm{C}-0$ Food in general, presented lower mean values than $10^{\circ} \mathrm{C}-0$-Food for each larval stage (Fig. 3). The number of replicates was too low to include FF in the ANOVA. Treatments with 0-Food also presented a lower \%S-phase than High-Food, and among them the $10^{\circ} \mathrm{C}$ treatments were the lowest. Differences in the \%S-phase between developmental stages did not reveal any consistent pattern (Fig. 4) and no significant interactions or main effects were found for this factor (Table 6). The ANOVA analysis for $\% \mathrm{G}_{2}-\mathrm{M}$ did not show any significant effect of food, temperature or their 
TABLE 6. - Results of the ANOVA with \% S-phase on day 5. as dependent variable experimental (Only Pre-M and Post-M stages included). $\mathrm{T}$, temperature; DS, developmental stage; df, degrees of freedom; MS, mean squares; F, F value; $p$, level of significance. Asterisks denote level of significance: $* p<0.05 ; * * p<0.01 ; * * *<<0.001$

\begin{tabular}{|c|c|c|c|c|c|c|}
\hline Factors and interactions & df effect & MS effect & df error & MS error & $\mathrm{F}$ & $\mathrm{p}$ \\
\hline $\mathrm{T}$ & 1 & 8.709 & 4 & 0.343 & 25,42 & $0.007 * *$ \\
\hline DS & 1 & 0.010 & 4 & 1.108 & 0.009 & 0.928 \\
\hline Food & 1 & 82.99 & 4 & 0.343 & 242.3 & $0.000 * * *$ \\
\hline Tank & 4 & 0.343 & 59 & 1.489 & 0.230 & 0.920 \\
\hline T x DS & 1 & 2.508 & 4 & 1.108 & 2.264 & 0.207 \\
\hline T x Food & 1 & 4.221 & 4 & 0.343 & 12.32 & $0.025 *$ \\
\hline DS x Food & 1 & 3.854 & 4 & 1.108 & 3.469 & 0.136 \\
\hline DS x Tank & 8 & 1.108 & 59 & 1.489 & 0.744 & 0.566 \\
\hline T x DS x Food & 1 & 1.166 & 4 & 1.108 & 3.760 & 0.125 \\
\hline
\end{tabular}

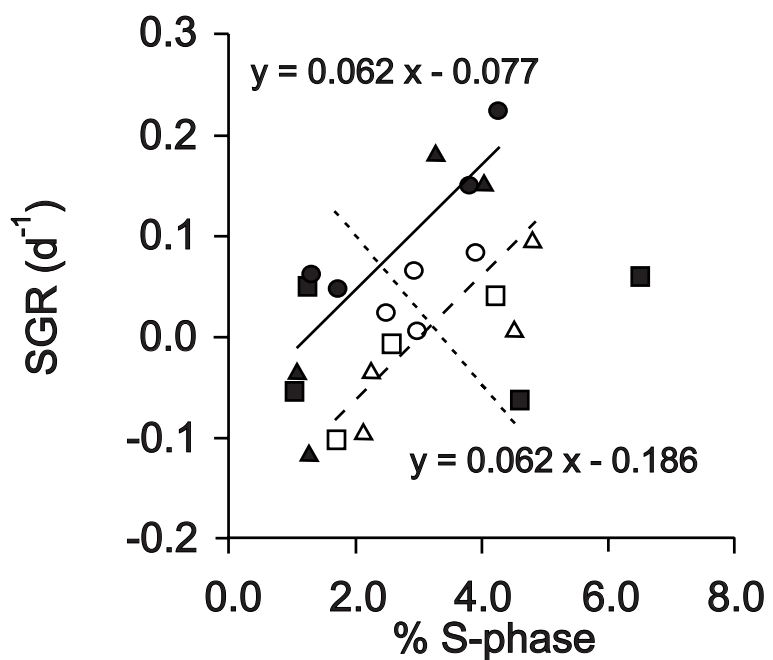

FIG. 6. - Relationship between mean standard growth rate (SGR, d $\left.{ }^{1}\right)$ against mean $\% \mathrm{~S}$-phase in each experimental treatment. Open symbols correspond to $6^{\circ} \mathrm{C}$ and filled symbols to $10^{\circ} \mathrm{C}$. Squares correspond to FF larvae; triangles to Pre.M larvae and circles PostM larvae (as defined in Fig. 3 caption). Continuous and dashed lines and their corresponding equations represent linear regression fits for 10 and $6^{\circ} \mathrm{C}$ treatments respectively $\left(\mathrm{r}^{2}\right.$ values are given in the text). The dotted line is used as a visual reference to differentiate 0 Food (below and to the left) from High-Food (above and to the right).

interaction (data not shown), and for $\% \mathrm{G}_{0}-\mathrm{G}_{1}$ only food was significant $(p=0.023)$.

The SGRs from each experimental treatment were positively related to their corresponding average \%S-phase in general (Fig. 6). However, the estimated SGRs of FF larvae at $10^{\circ} \mathrm{C}-$ High-Food tanks were low compared to their corresponding \%S-phase values, and SGR was negative in one case (with $\% \mathrm{~S}$ 4). However, the SGR of FF larvae from one of the $10^{\circ} \mathrm{C}-0$-Food tanks was positive. This inconsistency between SGR and $\% \mathrm{~S}$ for FF larvae at $10^{\circ} \mathrm{C}$ was not observed between MYO-SL adjusted means (Fig. 3 ) and $\% \mathrm{~S}$ (Fig. 4). We decided to exclude FF larvae at $10^{\circ} \mathrm{C}$ from the ANCOVA and the subsequent linear regression model since this group had also experienced unexpected high mortality (Table 3), possibly due to transfer stress. There were no significant differences between the slopes of linear regression fits of SGR against $\%$ S-phase for 6 and $10^{\circ} \mathrm{C}(\mathrm{n}=19$; $\mathrm{F}=1.68 ; \mathrm{p}>0.20)$. However, there were significant differences between the intercepts $(\mathrm{n}=19 ; \mathrm{F}=19.7$; $\mathrm{p}<0.001)$. A linear regression model, considering different intercepts and forcing equal slopes for each temperature, explained $73.8 \%$ of the variability $\left(\mathrm{n}=19 ; \mathrm{r}^{2}=73.8 ; \mathrm{F}=22.6 ; p<0.001\right)$ and showed that for the same value of $\% \mathrm{~S}$-phase, SGR was 0.11 higher at $10^{\circ} \mathrm{C}$ than at $6^{\circ} \mathrm{C}$ (Fig. 6). According to the regression equations (Fig. 6), the limit between positive and negative SGR was at 1.24 and $3.00 \% \mathrm{~S}$ phase for 10 and $6^{\circ} \mathrm{C}$ respectively.

\section{DISCUSSION}

The growth rates of cod larvae within the rearing tanks in this study are comparable with results from other studies from the same facility. The estimated time from hatching until initiation of metamorphosis $(12 \mathrm{~mm})$, was approx. 31 and 46 days at 10 and $6^{\circ} \mathrm{C}$ respectively. This is about four days longer than in the study by Otterlei et al., (1999) at the same temperatures, but about 4 days shorter than observed in full ration groups in a subsequent study (Høie et al., 2003). The growth rates from the lab studies have previously been shown to be of similar magnitude as those observed from mesocosm after temperature correction (Folkvord, 2005), and we therefore conclude that the High-Food groups had a normal growth pattern up to the time of experimentation.

Our general objective was to test the adequacy of cell cycle analysis to study the effect that food availability and temperature have on larval growth. We set an experimental design with contrasting factor conditions in order to generate differentiated larval 
growth rates. It should be noted that mortality rates of FF larvae were higher and more variable than at Pre-M and Post-M stages. It seems that not all fed-FF larvae were in good condition and therefore not growing at the expected rate. This interpretation is consistent with higher variability in SL, MYO and $\%$ S-phase in FF larvae compared with later stages, which presented lower and less variable mortality rates. Some larvae which would have recently metabolized energy from yolk may have further amplified the spread in larval condition at the FF stage.

The small brain size in FF larvae made dissecting them difficult and tissue loss often occurred. This fact may have been the reason for the high percentage of samples rejected due to a low number of cells $(<6000$ CCE $)$ and questions the applicability of this technique in small-sized larvae. However, the number of cells seemed to be enough for the analysis in most FF larvae. Refinement of the dissecting and manipulating techniques may improve the success rate. It should be noted that muscle must be the target tissue in the analysis of larval growth variability in field studies, which is the main purpose of condition indices. Larval growth is mainly attained by an increase in muscle mass and other tissues, such as brain, may not scale isometrically with growth at different developmental stages. Furthermore, muscle is more sensitive to unfavourable conditions than brain. However, we were unable to obtain samples of an acceptable quality for cell cycle analysis from muscle samples in preliminary trials with Sparus aurata and Catalan et al. (2007) obtained only $30 \%$ of samples with $\mathrm{CV}<6$, which they used as their quality threshold. Neural tissue is softer and it was easier to obtain cell suspensions with a low percentage of debris and aggregates. However, stronger mechanical force is needed to obtain cell suspensions from muscle. Therefore, a higher percentage of debris may be generated, resulting in low quality samples for cell cycle analysis. Successfully applying this technique to muscle largely depends on developing an appropriate technique for obtaining cell suspensions with low amounts of debris and aggregates.

Under the experimental conditions and methods in our study, and according to observed larval growth patterns, the $\% \mathrm{~S}$-phase was a better proxy for cell division rate than $\% \mathrm{G}_{2}-\mathrm{M}$ or $\% \mathrm{G}_{0}-\mathrm{G}_{1}\left(\%_{\mathrm{G}_{0}}\right.$ $\left.\mathrm{G}_{1}=100-\left(\% \mathrm{~S}+\% \mathrm{G}_{2}-\mathrm{M}\right)\right)$. Previous studies have used the total percentage of $\mathrm{S}+\mathrm{G}_{2}-\mathrm{M}$ (Theilacker and Shen, 1993a, b; 2001; Catalan et al. 2007) or the ratio $\left(\mathrm{G}_{2}-\mathrm{M}\right) /\left(\mathrm{G}_{0}-\mathrm{G}_{1}\right)$ as indices of cell division rate. Whereas $\mathrm{S}+\mathrm{G}_{2}-\mathrm{M}$ may be a better proxy for the total number of cells dividing and it apparently increases the power of statistical analysis, Shankey et al. (1993) recommended that only \% Should be used as the index of cell division rate. They argued that $\mathrm{G}_{2}-\mathrm{M}$ measurements have greater variability than S-phase due to the arrest of cells in $G_{2}$-phase and aggregates overlying $\mathrm{G}_{2}-\mathrm{M}$. Our results agree with the argument that $\% \mathrm{~S}$-phase is a better estimate of cell proliferation than $\% \mathrm{~S}+\mathrm{G}_{2}-\mathrm{M}$. However, Bromhead et al. (2000) reported that including Sphase data in their cell division index $\left(\mathrm{CDI} ; \mathrm{G}_{2}-\right.$ $\mathrm{M} / \mathrm{G}_{0}-\mathrm{G}_{1}$ ) had little or no effect on the statistical significance of their results. The software used to model cell cycle phases $\left(\mathrm{G}_{0}-\mathrm{G}_{1}, \mathrm{~S}\right.$ and $\left.\mathrm{G}_{2}-\mathrm{M}\right)$ calculates the percentage of cells in each phase. Therefore, $G_{0}-G_{1}=100-\left(S+G_{2}-M\right)$, so it is not surprising that $\% \mathrm{~S}$ had little effect on their $\mathrm{CDI}$ as it is already indirectly included in it. For a fixed percentage of $\mathrm{G}_{2}-\mathrm{M}$, if $\% \mathrm{~S}$ increases, $\mathrm{G}_{0}-\mathrm{G}_{1}$ (the denominator) decreases, and the CDI will have a higher value. In essence, the CDI is positively related and behaves similarly to the total percentage of $S$ $+\mathrm{G}_{2}-\mathrm{M}$ used in other studies (Theilacker and Shen, 1993a, b; 2001; Catalan et al. 2007). Still, the absence of $\mathrm{G}_{2}-\mathrm{M}$ significance in our study may be related to larger numbers of aggregates caused by methodological procedures and difficulties in their appropriate estimation, more than theoretical considerations such as arrest in $\mathrm{G}_{2}$. Even low aggregates may exert important variability when calculating $\mathrm{G}_{2}-$ M (Shankey et al., 1993). Light scatter measured by a flowcytometer is related to particle size. A procedure frequently used to differentiate $\mathrm{G}_{2}-\mathrm{M}$ from aggregates is to separate them by their pattern in light scatter, based on the assumption that aggregates may be larger than cells in the $\mathrm{G}_{2}-\mathrm{M}$ phase. However, we did not observe two clearly differentiated populations and there was no consistent pattern in the samples. It should be taken into account that within larval brains there may be differences in cell sizes that may cause some degree of overlap between $\mathrm{G}_{2}-\mathrm{M}$ and aggregates. Furthermore, the pattern of this overlap may change as proportions of cell sizes vary during larval development. Until better techniques are developed to appropriately differentiate aggregates and $\mathrm{G}_{2}-\mathrm{M}$, at least $\% \mathrm{~S} v s . \% \mathrm{~S}+$ $\mathrm{G}_{2}-\mathrm{M}$ must be evaluated to assess their relative predictive power with each specific methodology used (Bauer et al., 1993), including target tissue. 
Nevertheless, \%S-phase in brain cells in our study was significantly related to food and temperature, the interaction between both factors in the Pre$\mathrm{M}$ and Post-M stages and consistent with the observed pattern in FF larvae. Larvae presented a higher increase in the \%S-phase under High-Food conditions, which is in agreement with patterns of $\mathrm{S}$ $+\mathrm{G}_{2}-\mathrm{M}$ observed in previous studies (Theilacker and Shen, 1993a, b, 2001; Bromhead et al., 2000; Catalan et al., 2007). High \%S-phase at High-Food was coincident with high SL and adjusted means from the morphological relationship between MYO and SL (a proxy for individual larval weight). Our results suggest that cell cycle analysis may be appropriate as a growth index under contrasting feeding conditions.

There was no significant difference in $\% \mathrm{~S}$-phase for fully-fed larvae at different temperatures (6 and $10^{\circ} \mathrm{C}$ ), which was in agreement with the absence of significant differences in $\mathrm{G}_{2}-\mathrm{M} / \mathrm{G}_{0}-\mathrm{G}_{1}$ observed in larvae of Galaxias olidus reared at 12 and $16^{\circ} \mathrm{C}$ (Bromhead et al., 2000). In our case, this result was unexpected as Otterlei et al. (1999) showed that growth rate of cod larvae increased at temperatures from 4 to $14^{\circ} \mathrm{C}$, which is in agreement with the pattern observed in our rearing tanks (Fig. 2). The rate of increase in SGR with \%S-phase was similar at each temperature (no significant differences between slopes), but SGR was higher at a certain $\%$ S-phase value at $10^{\circ} \mathrm{C}$ (significant differences between intercepts). The cause of this temperature dependency on the relationship between growth and $\%$ S-phase is as still unclear. We suggest that temperature affects the rate at which cells progress through the cell cycle, as shown in previous studies on different organisms (West et al., 1981; Crossen, 1985; Francis and Barlow, 1988). Cell division rate for any one cell may be faster in larvae at $10^{\circ} \mathrm{C}$ than at $6^{\circ} \mathrm{C}$ (Aksnes et al., 2006). The brain would grow faster at $10^{\circ} \mathrm{C}$ as the duration of the cell cycle is shorter at higher temperatures, although the proportion of cells in the brain cycling at any one time may not increase. Hence, temperature should be considered as a second independent variable, like in the RNA/DNA index (Buckley, 1984). However, the RNA/DNA index is inversely related to temperature at a given growth rate. Increased RNA at low temperatures has been proposed to be a compensatory response by cells to ensure that basic metabolic processes are maintained despite the slowing of biochemical reaction rates due to low temperatures [see review by Bergeron (1997)]. Our results do not suggest a temperature-compensatory response in the percentage of cells dividing.

In addition, larvae from $6^{\circ} \mathrm{C}$ at 0 -Food presented a significantly higher $\% \mathrm{~S}$-phase than larvae from $10^{\circ} \mathrm{C}$ at 0 -Food. Metabolic costs increase with temperature in larval cod (Finn et al., 2002). Therefore, cell division would be less affected by suboptimal food availability at low temperatures. Although we should not expect a reduction in SL under low food availability, we can expect this to occur in terms of larval weight as a consequence of metabolic costs. This is consistent with the pattern in the morphometric relationship between MYO and SL; larvae at $6^{\circ} \mathrm{C}-0$-Food presented higher MYO in relation to SL compared with larvae at $10^{\circ} \mathrm{C}-0$-Food (although not significant). The interaction between food and temperature, mediated by temperature dependency of metabolic costs, may play a significant role in larval growth rate variability in the field, which increases with temperature (Houde, 1989, Buckley et al., 2004). However, the magnitude of this effect in terms of \% S-phase should be interpreted with caution. As suggested by the absence of differences in $\% \mathrm{~S}$ at High-Food conditions at different temperatures, the rate of cell proliferation in a tissue may depend both on the percentage of cells 'cycling' and on the rate at which individual cells progress through the cell cycle, which could be temperature dependent. Nevertheless, the capability of cell cycle analysis to detect growth differences at low temperatures is a potential advantage over RNA indices, as the compensatory increase in RNA at suboptimal temperatures reduces their sensitivity (Bergeron, 1997). A simultaneous analysis of RNA and cell cycle based indices may confirm this hypothesis.

The absence of a significant effect of developmental stage on the \%S-phase or its interaction with other factors was also an unexpected result. We expected a larger percentage of cells dividing at larval stages characterized by higher growth rates (e.g. pre-metamorphosis stages (Otterlei et al., 1999)). However, Pre-M larvae did not have higher SGR than Post-M larvae. Between-individual variability in SL and MYO within each experimental tank may account for part of the variability in SGR estimates. In addition, the SL at which cod larvae attained maximum growth rates may have varied between 6 and $10^{\circ} \mathrm{C}$ during experimental treatments. Growth allometry between different tissues may be an alter- 
native explanation. In other fish, brain growth proceeds at a lower rate than body weight. The relationship between body mass, SL and MYO shows 3 distinct phases during cod ontogeny (Finn et al., 2000), and the larval sizes that determined developmental stage in our study fitted each of these phases. Body mass increases at a higher rate in relation to SL between 7 and $12 \mathrm{~mm}$, which is concurrent with a higher rate of increase in MYO with respect to SL (Finn et al., 2002). Higher growth rate in premetamorphosis stages (Otterlei et al., 1999) seems to be related to morphological changes, and may not scale isometrically with brain growth. Muscle tissue is more suitable to test for differences in growth variability related to ontogeny. However, muscle growth in larval cod can be either in the form of growth in fibre numbers (hyperplasia) or fibre size (hypertrophy) (Galloway et al., 1999), and in a follow-up study it would be recommended to measure the total DNA content (as a measure of cell numbers) to see if this increase corresponds to the increase in dry weight (as a measure of total cell mass). The apparent discrepancy may also be due to growth phases in cell numbers as opposed to increases in cell size. Furthermore, larval development also includes tissue remodelling, in which apoptosis (programmed cell death) plays an important role (Yamashita, 2003). At certain developmental stages, apoptosis could represent a significant fraction compared to cell division in a specific tissue. Taking into account high characteristic growth rates in larval stages, we assumed that growth was mainly attained by cell division, at least in neural tissues. However, growth rate is in fact the consequence of cell division (positive growth) and apoptosis (negative growth), and their relative proportion changes during larval development and possibly under unfavourable conditions (e.g. fasting). Apoptosis can be estimated by flow cytometry and it is necessary to determine its relative importance and evaluate whether it is appropriate to include it in a cell cycle based index.

The linear regression between SGR and the $\% \mathrm{~S}$ phase in our study explained a higher amount of the variance $(74 \%)$ than the regression between growth rate $\left(\mathrm{AGR}, \mathrm{mm} \mathrm{d}^{-1}\right)$ and $\%(\mathrm{~S}+\mathrm{G} 2)$ obtained by Theilacker and Shen (2001) in muscle tissue of Theragra chalcogramma larvae under different feeding conditions $(54 \%)$. This is somewhat lower than that obtained using RNA:DNA ratios in a study on herring larvae (Folkvord et al., 1996), in which multiple regression models explained up to $90 \%$ of the variability in average growth. A likely explanation for this difference is that most of the RNA and DNA in RNA:DNA analyses originate from relatively responsive muscle tissue as opposed to less nutritionally dependent brain cells.

In summary, the results presented herein support the argument by Theilacker and Shen (1996) that analyzing the cell cycle by flow cytometry may be an adequate growth index in fish larval studies. As in previous studies (Theilacker and Shen, 1992a, b, 2001; Bromhead et al., 2000), our study suggests that cell cycle analysis by flow cytometry is appropriate for analyzing growth variability related to food availability. Furthermore, under food deprivation, the observed \%S-phase variability was consistent with the effect that temperature has on metabolic costs. The absence of significant differences in the $\% \mathrm{~S}$-phase under different temperatures may be the consequence of a temperature dependence of the duration of the cell cycle in a single cell. This effect should be tested under a wider range of temperature conditions.

\section{ACKNOWLEDGEMENTS}

We are grateful to A. Salas from the Servicio de Citometría e Inmunotecnología of the Universidad de Oviedo for her advice on cell cycle issues and first proofs with fish larvae. J. Cigarría (Tina Menor S.A.) provided us Sparus aurata larvae for the first trials in cell cycle analysis. C. Booman arranged every detail above and beyond what was expected for a fruitful and pleasant stay for R. G.-Q. and I. M. during experimental and analysis runs in Bergen. Eggs were provided by Dr. H. Otterå, IMR Parisvatnet. We are indebted to F. Midtøy, E. Otterlei, B. Sveinsb $\varnothing$, P. Løvik and all the members and students of the Department of Fisheries and Marine Biology involved in the experimental run in spring 2001 for their technical assistance and help. Dr. R.N. Finn is thanked for providing raw data for the morphometric relationship used in this study. Prof. B. Åsjø put at our service the flow cytometer at the HIB. Comments from reviewers contributed to improving the manuscript. The work presented in this study was financed by the project HPRI-CT1999-00056, Bergen Marine Food Chain Research Infrastructure (Improving Human Potential Program from the European Commission). R. G.-Q. held a 
fellowship from the research project 1FD97-1045C02-01 (European Union - CICYT (Spain), FEDER). Experiments were within the guidelines of the local animal research board.

\section{REFERENCES}

Aksnes, D.L., C. Troedson and E.M. Thompson. - 2006. A model of developmental time applied to planktonic embryos. Mar. Ecol. Prog. Ser., 318: 75-80.

Bauer, K.D., B. Bagwell, W. Giaretti, M. Melamed, R.J. Zarbo, T.E. Witzig and P.S. Rabinovitch. - 1993. Consensus review of the clinical utility of DNA flow cytometry in colateral cancer. Cytometry, 14: 486-491.

Bergeron, J.-P. - 1997. Nucleic acids in ichthyoplankton ecology: a review, with emphasis on recent advances for new perspectives. J. Fish Biol., 51 (Suppl. A): 284-302.

Bromhead, D., J. Kalish and P. Waring. - 2000. Application of flow cytometry cell cycle analysis to the assessment of condition and growth in larvae of a freshwater teleost Galaxias olidus. Can.J. Fish. Aquat. Sci., 57: 732-741.

Buckley, L. J., E.M. Caldarone and G. Lough. - 2004. Optimum temperature and food-limited growth on larval Atlantic cod (Gadus morhua) and haddock (Melanogrammus aeglefinus) on Georges Bank. Fish. Oceanog., 13: 134-140.

Buckley, L.J., S.I. Turner, T.A. Halavik, A.S. Smigielski, S.M. Drew, and G.C. Laurence. - 1984. Effects of temperature and food availability on growth, survival, and RNA-DNA ratio of larval sand lance (Ammodytes americanus). Mar. Ecol. Prog. Ser., 15: 91-97.

Catalán, I.A., E. Berdalet, M.P. Olivar and C. Roldán. - 2007. Response of muscle-based biochemical condition indices to short-term variations in food availability in post-flexion reared sea bass Dicentrarchus labrax (L.) larvae. J. Fish. Biol. 70: 1-15.

Clemmensen, C. and T. Doan. - 1996. Does otolith structure reflect the nutritional condition of a fish larva? Comparison of otolith structure and biochemical index (RNA/DNA ratio) determined in cod larvae. Mar. Ecol. Prog. Ser., 138: 33-39.

Cooper, G. M. - 2000. The Cell - A Molecular Approach. Sinauer Associates, Sunderland, Massachusetts.

Crossen, P.E. - 1985. The effect of temperature and cell cycle length on SCE frequency in Rat-1 cells. Mutat. Res., 149: 101-104.

Darzynkiewicz, Z., P. Smolewski and E. Bedner. - 2001. Use of flow and laser scanning cytometry to study mechanisms regulating cell cycle and controlling cell death In: J.P. McCoy Jr., and D.F. Keren (eds), New applications of flow cytometry, pp. 857-873. Elsevier Science, Philadelphia, Pennsylvania.

Ellertsen, B., P. Solemdal, T. Strømme, S. Tilseth, T. Westgård and E. Moksness, E. - 1980. Some biological aspects of cod larvae (Gadus morhua L.). Fisk Dir. Skr. Ser. Hav.Unders., 17: 29-47.

Ferron, A. and W.C. Leggett. - 1994. An appraisal of condition measures for marine fish larvae. Adv. Mar. Biol., 30: 216-303.

Finn, R.N., I. Rønnestad, T. van der Meeren and H.J. Fyhn. - 2002. Fuel and metabolic scaling during the early life stages of Atlantic cod Gadus morhua. Mar. Ecol. Prog. Ser., 243: 217-234.

Folkvord, A. - 2005. Comparison of size-at-age of larval cod (Gadus morhua L.) from different populations based on sizeand temperature-dependent models. Can. J. Fish. Aquat. Sci. 62: 1037-1052.

Folkvord, A., K. Rukan, A. Johannessen and E. Moksness. - 1997. Early life history of herring larvae in contrasting feeding environments determined by otolith microstructure analysis. J. Fish Biol., 51: 250-263.

Francis, D. and P.W. Barlow, P.W. - 1988. Temperature and cell cycle. Symp. Soc. Exp. Biol., 42: 181-201.

Galloway, T.F., E. Kjørsvik and H. Kryvi. - 1999. Muscle growth and development in Atlantic cod (Gadus morhua L.) related to different somatic growth rates. J. Exp. Biol., 202: 2111-2120.

García, A., D. Cortés, T. Ramírez, C. Guisande, J. Quintanilla, F. Alemany, J.M. Rodríguez, J.P. Álvarez and Á. Carpena. 2007. Field comparison of sardine post-flexion larval growth and biochemical composition from three sites in the W Mediterranean (Ebro river coast, bays of Almería and Málaga). Sci.Mar., 70S2: 79-91.

Hedley, D.W., T.V. Shankey and L.L. Wheeless. - 1993. DNA Cytometry Consensus Conference. Cytometry 14: 471.

Høie, H., A. Folkvord and E. Otterlei. - 2003. Effect of somatic and otolith growth rate on stable isotopic composition of early juvenile cod (Gadus morhua) otoliths. J. Exp. Mar. Biol. Ecol., 289: 41-58.

Houde, E.D. - 1987. Fish early life dynamics and recruitment variability. Am. Fish. Soc. Symp. 2: 17-29.

Houde, E.D. - 1989. Comparative growth, mortality and energetics of marine fish larvae: temperature and implied latitudinal effects. Fish. Bull. US, 87: 471-495.

Houde, E.D. - 1997. Patterns and trends in larval-stage growth and mortality of teleost fish. J. Fish Biol., 51(Suppl. A): 52-83.

Leggett, W.C. and E. Deblois. - 1994. Recruitment in marine fishes: is it regulated by starvation and predation in the egg and larval stages? Neth. J. Sea Res., 32: 119-134.

Otterlei, E., G. Nyhammer, A. Folkvord and S.O. Stefansson. 1999. Temperature- and size-dependent growth of larval and early juvenile Atlantic cod (Gadus morhua): a comparative study of Norwegian coastal cod and northeast Arctic cod. Can. J. Fish. Aquat. Sci., 56: 2099-2111.

Pepin, P. - 1991. Effect of temperature and size on development, mortality, and suavival rates of the pelagic early life history stages of marine fish. Can. J. Fish. Aquat. Sci., 48: 503-518.

Pepin, P. and R.A. Myers. - 1991. Significance of egg and larval size to recruitment variability of temperate marine fish. Can.J. Fish. Aquat. Sci., 48: 1820-1828.

Shankey, T.V., P.S. Rabinovitch, B. Bagwell, K.D. Bauer, R.E. Duque, D.W. Hedley, B.H. Mayall and L.L. Wheeless. - 1993. Guidelines for implementation of clinical DNA cytometry. Cytometry, 14: 472-477.

Theilacker, G.H. and W. Shen. - 1993a. Calibrating starvationinduced stress in larval fish using flow cytometry. Am. Fish. Soc. Symp., 14: 85-94.

Theilacker, G.H. and W. Shen. - 1993b. Fish larval condition analyzed using flow cytometry. In: B.T. Walter. and H.J. Fyhn (Eds), Physiological and biochemical aspects of fish development, pp. 346-355. University of Bergen, Norway.

Theilacker, G.H. and W. Shen. - 2001. Evaluating growth of larval walleye pollock, Theragra chalcogramma, using cell cycle analysis. Mar. Biol., 138: 897-907.

Theilacker, G.H., K.M. Bailey, M.F. Canino and S.M. Porter. 1996. Variations in larval walleye pollock feeding and condition: a synthesis. Fish. Oceanog., 5(Suppl 1): 112-123.

Underwood, A.J. - 1997. Experiments in Ecology. Cambridge University Press. Cambrige. 504 pp.

Yamashita, M. - 2003. Apoptosis in zebrafish development. Comp. Biochem. Physiol. B-Biochem Mol. Biol. 136: 731-742.

van der Meeren, T. - 1991. Selective feeding and prediction of food consumption in turbot larvae (Scophthalmus maximus L.) reared on the rotifer Brachionus plicatilis and natural zooplankton. Aquaculture, 93: 35-55.

West, J., M.J. Lyttleton and F. Gianelli. - 1981. Effect of incubation temperature on the frequency of sister cromatid exchanges in Bloom's syndrome lymphocites. Hum. Genet., 59: 204-207.

Westerman, M.E., G.J. Holt. and L. DiMichele. - 1999. Quantitative assy of cyclin-dependent kinase activity as a sensitive marker of cell proliferation in marine teleost larvae. Mar. Biotechnol., 1: 297-310.

Scient. ed.: M.P. Olivar.

Received July 7, 2006. Accepted April 19, 2007.

Published online July 9, 2007. 
